\title{
The Influence of Local Geology on the Groundwater Potential of Kunike Sanda and Barina Chiefdoms Tonkolili District Northern Sierra Leone
} Yaguba Jalloh $^{1 *}$, Kyuro Sasaki ${ }^{1}$ and Mustapha Olajiday Thomas ${ }^{2}$

${ }^{1}$ Department of Earth Resources Engineering, Faculty of Engineering, Kyushu University, Fukuoka 819-0395, Japan

${ }^{2}$ Department of Geology, Faculty of Pure and Applied Sciences, Fourah Bay College, Freetown, Sierra Leone

\begin{abstract}
This research investigated the influence of the local geology on the groundwater potential of the two kunike chiefdoms (Sanda and Barina) in the Tonkolili District, Northern Sierra Leone. The local geology is made up of rocks typical of the West African Archean greenstone belt. The stratigraphic sequence is marked by the basic ultramafics followed by mafics (metavolcanics) and a metasedimentary unit i.e., quartzite and banded iron formations in a greenstone belt lying on or beside granitic basement rocks. The basement relationship of the granites to the supracrustals has been obliterated by intrusion of Late-Kinematic granites and by deformation and metamorphism during the Liberian tectonothermal event $(=2700 \mathrm{Ma})$ which produced the dominant $\mathrm{N}-\mathrm{S}$ to NNE-SSW trend. Because of the geology, aquifers in the studied area are located in two different lithologies-granitic terrain and schist belt. Aquifer characteristics such as transmissivity and yield were measured and compared for the different lithologies. Comparison results show that the yield is greater $(0.03 \%)$ in the granitic terrain than in the schist belt. And this is because of the presence of clays in the schist belt. The research also revealed that groundwater is readily available in the area.
\end{abstract}

Keywords: Geology; Groundwater; Aquifers; Sierra Leone; Surface water

\section{Introduction}

Sierra Leone forms parts of the West African Craton. About 70\% of the outcrops are older than 2.1 G.a. These rocks have been affected by many tectonic events and the structures produced have been used to unravel the geological history of the country. The country consists mainly of an Archaean granite greenstone terrain bounded in the West by a West ward dipping zone of intense high grade rocks, this forms the Kasila group and it has been interpreted as suture. East wards the granite-greenstone terrain is bounded by low grade metamorphic rocks of the Marampa group where the project area is found. The water output of the boreholes in the area is largely dependent on the surrounding geology.

Majority of the population in the district depend on groundwater for domestic use and other purposes. However, in spite of the high potential of groundwater in this region and the number of boreholes drilled by Aid Agencies, study reveals that there is still a serious problem with adequate availability and quality of groundwater. This is very evident from long queues at local and drilled wells of people scrambling for water and the high amount of water related diseases reported at health centers in the project area.

\section{Location of the Project Area}

It lies between longitude $11^{\circ} 42^{1}$ and $11^{\circ} 27^{1}$ west of Greenwich and latitude $8^{\circ} 42^{1}$ and $8^{\circ} 33^{1}$ north. It lies within sheet 56 and 57 of the 1:50.000 contoured plain metric map of Sierra Leone. Figure 1 shows the topographic map of Sierra Leone. The studied area covered the following localities of Makali, Mathonkara, Makoni Line, Petifu Line, Masingbi, Masaba, Machain, Magbasia, Bumbe and a host of other villages.

\section{Geology of the Project Area}

The geology of Tonkolili forms the syntectonic to late tectonic plutonic intrusions [1]. The intrusions range in size from large masses having gradational contact with the basement to smaller cross-cutting stocks and plutons down to pegmatite and aplites. They are mainly of granites to granodiorite in composition and include smaller masses of diorite, gabbro, syenite and other related rocks. The granites intrude both the basement and supracrustals and are therefore younger than the two. They are proposed to have been emplaced during the last of the reactivation events of the basement. The granitic intrusions vary in size from large elongate batholiths to small circular stocks.

The larger bodies tend to be foliated and many of them are porphyritic with feldspars reaching several centimeters in size. The smaller intrusions are unfoliated and generally fine grained. The larger granites are syn-tectonic i.e., they were emplaced during the climax and metamorphism of the basement.

The smaller granites are late-tectonic i.e., they were emplaced during the warning stage of deformation and metamorphism.

Figure 2 shows the geological map of Sierra Leone and the nine (9) comprising geological units.

\section{State of Existing Water Resources}

At present, the kunike Chiefdoms (Barina and Sanda) utilize both groundwater and surface water. Although surface water is in dominant use, about twenty (20) boreholes were visited in the entire project area

*Corresponding author: Yaguba Jalloh, Department of Earth Resources Engineering, Faculty of Engineering, Kyushu University, Fukuoka 819-0395, Japan, Tel: +23276503624; E-mail: yjalloh2003@yahoo.com

Received December 19, 2016; Accepted December 22, 2016; Published December 29, 2016

Citation: Jalloh Y, Sasaki K, Thomas MO (2016) The Influence of Local Geology on the Groundwater Potential of Kunike Sanda and Barina Chiefdoms Tonkolili District Northern Sierra Leone. Hydrol Current Res 7: 262. doi: 10.4172/2157 7587.1000262

Copyright: ( 2016 Jalloh Y, et al. This is an open-access article distributed under the terms of the Creative Commons Attribution License, which permits unrestricted use, distribution, and reproduction in any medium, provided the original author and source are credited. 


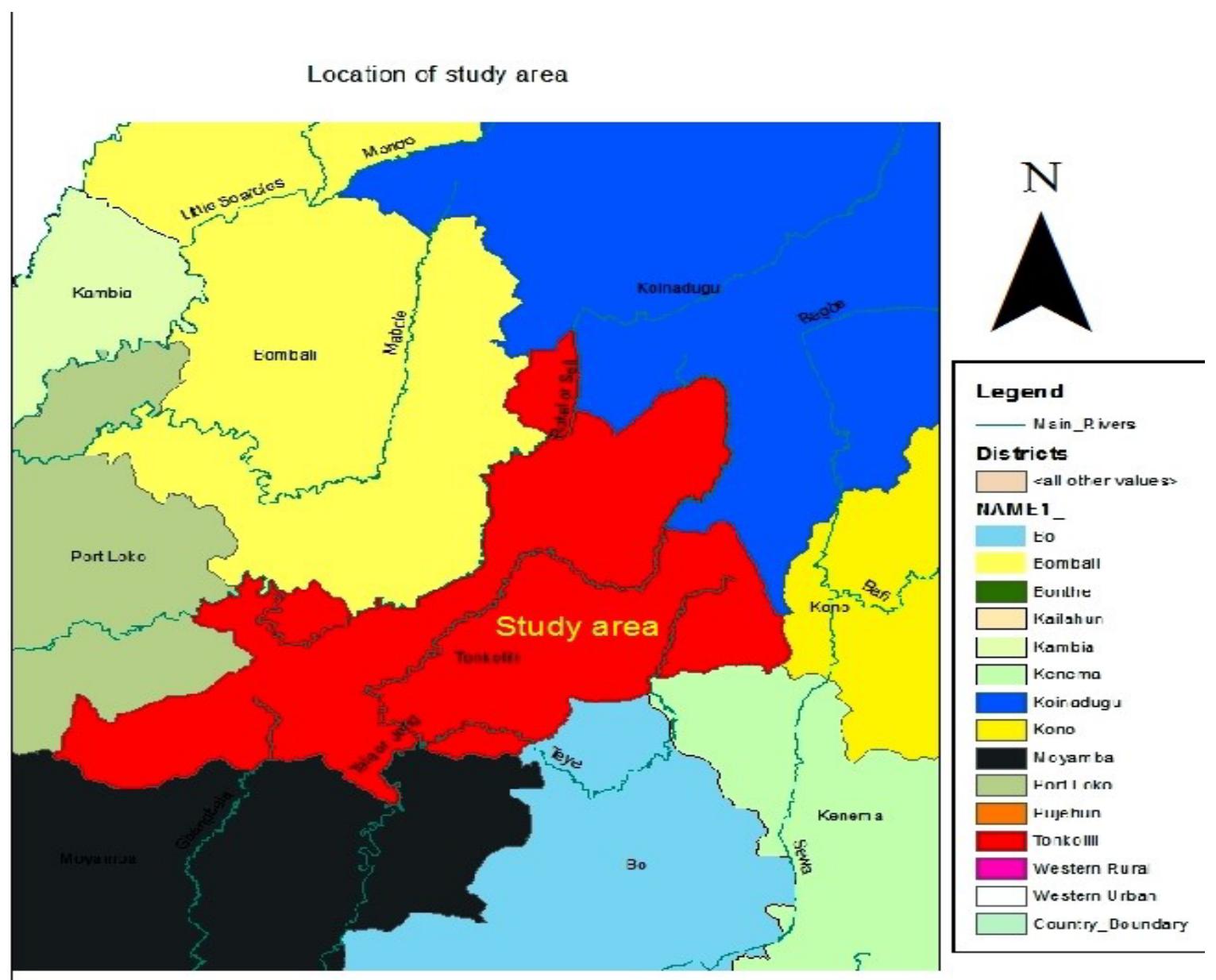

Figure 1: Topographic map of the Study Area

including a spring located between Barrainin and Makali along the Kono highway. Table 1 shows the locality name and coordinates of the sampled boreholes [2,3].

Most of the groundwater point sources were constructed by the local people with the exception of six (6) boreholes constructed by Sierra Leone Water Company-SALWACO. Other boreholes were constructed by TAKOR, a local NGO group involved in the plantation of trees and some help to the communities like building culvert bridges and construction of boreholes. Most of the boreholes are in relatively good sanitary condition and are located away from surface contaminants like pit latrines (Tables 2-4).

\section{Aquifer Condition in the Project Area}

By definition, any geological material that is sufficiently permeable to yield significant amount of water to pumping wells is called an aquifer. For a geological material to be an aquifer it should be porous and permeable.

The aquifers in the studied area are largely unconfined, that is the water table forms the upper surface of the zone of saturation. The aquifers are poorly consolidated, porous media consisting of sands and gravel. The occurrence, distribution and movement of groundwater is determined and controlled by the porosity produced by joints, fractures, and fissures within the basement rocks. Thus, in Sierra
Leone the aquifer system and their characteristics are largely related to the various geological formations in the country. Figure 3 shows the aquifer system of Sierra Leone.

Nonetheless, analysis of pumping test data for some boreholes in the area indicates that the aquifers receive some of their recharge from surface source.

Recharge may be estimated by using the water balance model to calculate actual evapotranspiration which is then fed into the hydrologic equation to determine groundwater recharge: The input parameters to the water balance model include; Temperature, Precipitation, Potential evapotranspiration, and surface runoff. The surface runoff coefficient for Sierra Leone rivers is 0.12 . The hydrologic equation is thus:

$$
R g=P-(S r-E v)
$$

Where, $\mathrm{Rg}=$ Groundwater recharge $(\mathrm{mm}) ; \mathrm{P}=$ Precipitation $(\mathrm{mm})$; $\mathrm{Sr}=$ Surface runoff $(\mathrm{mm}) ; \mathrm{Ev}=$ Evapotranspiration $(\mathrm{mm})$.

The aquifers found in the two chiefdoms consist of sand, gravel, silt, and weathered granite. Since the sediment have high porosity as a result of the pore spaces found in them it can be concluded that most of the aquifers in the project area are permeable to some extent [4].

The major rock formations found here that have greater potential of groundwater storage include: 


\begin{tabular}{|c|c|c|}
\hline No. & Locality & Coordinates \\
\hline 1 & Masingbi & $0227531 \mathrm{E}, 0955988 \mathrm{~N}$ \\
\hline 2 & Bonke & $0230964 \mathrm{E}, 0955306 \mathrm{~N}$ \\
\hline 3 & Makwalie & $0225807 \mathrm{E}, 0951774 \mathrm{~N}$ \\
\hline 4 & Mabathof & $0224523 \mathrm{E}, 0956400 \mathrm{~N}$ \\
\hline 5 & Mabgasia & $0223048 \mathrm{E}, 0953781 \mathrm{~N}$ \\
\hline 6 & Madina & $0219328 \mathrm{E}, 0954495 \mathrm{~N}$ \\
\hline 7 & Petifu Line & $0220362 \mathrm{E}, 0954576 \mathrm{~N}$ \\
\hline 8 & Petifu Chain & $0219092 \mathrm{E}, 0952877 \mathrm{~N}$ \\
\hline 9 & Makoni Line & $0216574 \mathrm{E}, 0955783 \mathrm{~N}$ \\
\hline 10 & Mathonkara & $0214194 \mathrm{E}, 0954396 \mathrm{~N}$ \\
\hline 11 & Barrainin & $0209641 \mathrm{E}, 0953807 \mathrm{~N}$ \\
\hline 12 & Makali & $0207039 \mathrm{E}, 0954891 \mathrm{~N}$ \\
\hline
\end{tabular}

Table 1: Locality visited during the data collection.

\begin{tabular}{|c|c|c|}
\hline \multirow{2}{*}{ Time (s) } & D.W.L & Drawdown \\
\cline { 2 - 3 } & $\boldsymbol{h}(\mathbf{m})$ & $\boldsymbol{h}-\boldsymbol{h}_{\mathbf{0}}(\mathbf{m})$ \\
\hline 30 & 4.92 & 0 \\
\hline 60 & 7.2 & 2.28 \\
\hline 120 & 9.2 & 4.28 \\
\hline 180 & 10.97 & 6.05 \\
\hline 240 & 12.19 & 7.27 \\
\hline 300 & 13.42 & 8.5 \\
\hline 360 & 14.9 & 9.98 \\
\hline 420 & 16.33 & 11.41 \\
\hline 480 & 17.6 & 12.68 \\
\hline 540 & 18.5 & 13.58 \\
\hline
\end{tabular}

Table 2: Measurement data at Makoni Line Borehole.

\begin{tabular}{|c|c|c|}
\hline \multirow{2}{*}{ Time (s) } & D. W. L & Drawdown \\
\cline { 2 - 3 } & $\boldsymbol{h}(\mathbf{m})$ & $\boldsymbol{h} \boldsymbol{h}_{\mathbf{0}}(\mathbf{m})$ \\
\hline 10 & 7.7 & 0 \\
\hline 60 & 10.49 & 2.79 \\
\hline 120 & 12.37 & 4.67 \\
\hline 180 & 13.53 & 5.83 \\
\hline 240 & 15.65 & 7.95 \\
\hline 300 & 16.26 & 8.56 \\
\hline 360 & 16.58 & 8.88 \\
\hline 420 & 16.66 & 8.96 \\
\hline 480 & 16.73 & 9.03 \\
\hline 540 & 16.78 & 9.08 \\
\hline 600 & 16.8 & 9.1 \\
\hline
\end{tabular}

Table 3: Measurement data at Petifu Line Borehole.

\begin{tabular}{|c|c|c|}
\hline \multirow{2}{*}{ Time (s) } & D. W. $\mathbf{~}$ & Drawdown \\
\hline 0 & $\boldsymbol{h}(\mathbf{m})$ & $\boldsymbol{h}_{\mathbf{~}} \mathbf{( m )}$ \\
\hline 60 & 8.6 & 0 \\
\hline 120 & 10.63 & 2.03 \\
\hline 180 & 13.49 & 4.89 \\
\hline 240 & 14.78 & 6.18 \\
\hline 300 & 16.22 & 7.62 \\
\hline 360 & 18.3 & 9.7 \\
\hline 420 & 19.58 & 10.98 \\
\hline 480 & 20.34 & 11.74 \\
\hline 540 & 20.87 & 12.27 \\
\hline 600 & 20.99 & 12.39 \\
\hline
\end{tabular}

Table 4: Measurement data at Masingbi Borehole.
I. The weathered layer-Nearly all handdug wells in the area penetrate this aquifer but recharge is generally low due to low transmissivity.

II. The zone between overburden and hard rock-This aquifer is very difficult to penetrate, but with favorable climatic conditions, weathering of the hard rock gives high prospects of exploiting this aquifer. Wells that penetrate this aquifer give water of good quality since water is filtered as it passes through the rocks.

III. The Hard Rock-This aquifer is very reliable but drilling through this aquifer requires special drilling techniques and for this reason drilling through these aquifers is done by hammer drilling method [5].

\section{Analysis and Interpretation of Pumping Test Data}

Pumping tests are carried out for the following reasons:

a) To determine the behavior of the aquifer during pumping in the borehole and for different yields to fix the maximum yield for exploitation compatible with the conditions of the aquifer.

b) To determine particularly the hydraulic characteristics of the aquifer around the borehole (i.e., transmissivity).

c) To determine that the water table of the reservoir do not over exploit the aquifer and to limit the yield according to the condition of the aquifer.

This method (pumping test) can be used for the determination of transmissivity and storativity. Two boreholes are needed in pumping test. The first one is the production well and the other is an observation well. Essentially water is pumped out of the production well, during this process the piezometric surface will fall and this is called a drawdown. However, in the project area only one borehole i.e., the production well was used during the pumping and as such certain assumptions needs to be made as it is only transmissivity is measurable in the boreholes in the project area [6]. No radius of influence, hence storativity cannot be estimated. In an ideal aquifer, the following assumptions are made in carrying out the pumping test as in the project area:

1) There is only a single pumping well in the aquifer.

2) The pumping rate is constant.

3) The well fully penetrate the aquifer

4) The hydraulic head (h) prior to pumping is uniform.

\section{Results and Discussion}

\section{Pumping test analysis}

The pumping test data during the SALWCO project implemented by KOREA GROUP are analyzed below. During the analysis, a semilogarithmic graph of drawdown versus time was plotted for each data. With the drawdown and the time values obtained, the transmissivity can be calculated using the following equation presented by Cooper et al. [7].

$$
h_{0}-h=\frac{2.3 Q}{4 \pi T} \log \frac{2.25 \pi}{r^{2} S}
$$

where: $\mathrm{h}_{0}=$ Static water level $(\mathrm{m})$; $\mathrm{h}=\mathrm{Head}$ at any level $(\mathrm{m})$; ho$\mathrm{h}=$ Drawdown for a logarithmic cycle $(=\Delta \mathrm{h})(\mathrm{m})$; $\mathrm{Q}=$ Discharge $\left(\mathrm{m}^{3} / \mathrm{s}\right)$; $\mathrm{T}=$ Transmissivity $\left(\mathrm{m}^{2} / \mathrm{s}\right) ; \mathrm{S}=$ Storativity $\left(\mathrm{m}^{2} / \mathrm{s}\right) ; \mathrm{r}=$ Radius of influence $(\mathrm{m}) ; \mathrm{t}=$ Time at zero drawdown (s). 


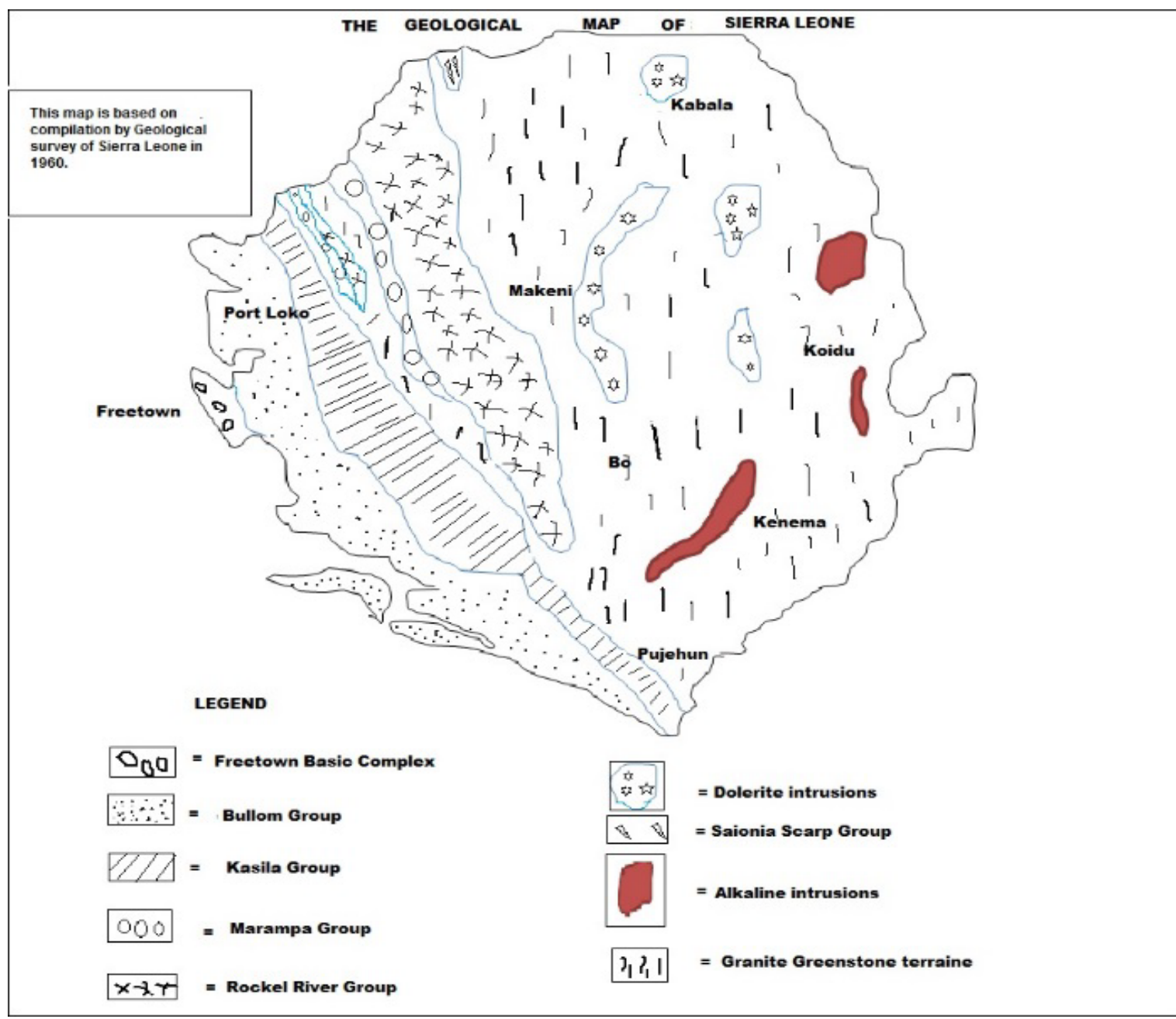

Figure 2: Geologic map of Sierra Leone.

Since there is only a single well in the aquifer with no observation well, so no radius of influence, hence storativity cannot be estimated. Transmissivity can be calculated as

$$
T=\frac{2.3 Q}{4 \pi \Delta h}
$$

The pumping test data of the selected boreholes in the project area are shown below with their analysis.

\section{Makoni line borehole}

Yield during pumping $=2.5 \mathrm{~m}^{3} / \mathrm{hr}$

Static water level (ho) $=4.94 \mathrm{~m}$

Temperature $=28^{\circ} \mathrm{C}$

Total dissolved solids $=88.9 \mathrm{mg} / \mathrm{L}$

Electrical conductivity $=117.8 \mathrm{Lls} / \mathrm{cm}$

$\mathrm{pH}=6.3$

Drawdown: $\Delta h=8.60 \mathrm{~m}$

Discharge: $Q=2.5 \mathrm{~m}^{3} / \mathrm{hr}$

Transmissivity: $T=\frac{2.3 Q}{4 \pi \Delta h}=\frac{2.3(2.5)}{4 \pi(8.60)}=0.053 \mathrm{~m}^{2} / \mathrm{s}$

\section{Petifu line borehole}

Yield during pumping: $1.8 \mathrm{~m}^{3} / \mathrm{hr}$

Static water level: $7.70 \mathrm{~m}$

Temperature: $27.5^{\circ} \mathrm{C}$

Total dissolved solids: $88.3 \mathrm{mg} / \mathrm{L}$

Electrical conductivity: $117.2 \mathrm{us} / \mathrm{cm}$

pH: 6.1

Drawdown: $\Delta h=6.40 \mathrm{~m}$

Discharge: $Q=1.8 \mathrm{~m}^{3} / \mathrm{hr}$

Transmissivity: $T=\frac{2.3 Q}{4 \pi \Delta h}=\frac{2.3(1.8)}{4 \pi(6.40)}=0.052 \mathrm{~m}^{2} / \mathrm{s}$

\section{Masingbi (School) borehole}

Yield during pumping $=1.4 \mathrm{~m}^{3} / \mathrm{hr}$

Static water level $=8.60 \mathrm{~m}$

Temperature $=27.4^{\circ} \mathrm{C}$

Total dissolved solids $=176 \mathrm{mg} / \mathrm{l}$ 


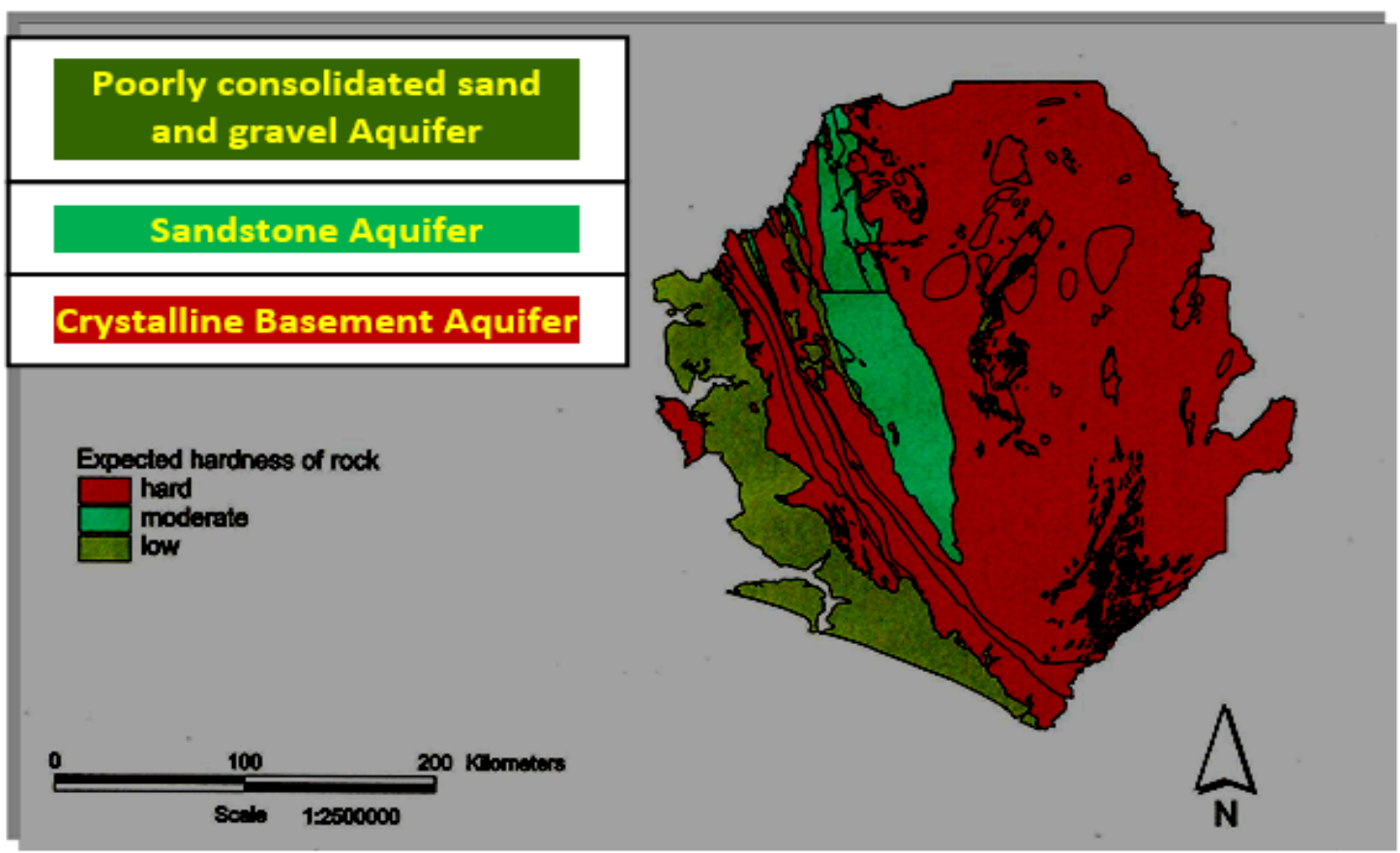

Figure 3: Aquifer map of Sierra Leone.

Electrical conductivity $=35.1 \mathrm{us} / \mathrm{cm}$

$\mathrm{pH}=6.1$

Drawdown: $\Delta h=9.20 \mathrm{~m}$

Discharge: $Q=1.4 \mathrm{~m}^{3} / \mathrm{hr}$

Transmissivity: $T=\frac{2.3 Q}{4 \pi \Delta h}=\frac{2.3(1.9)}{4 \pi(9.20)}=0.028 \mathrm{~m}^{2} / \mathrm{s}$

\section{Borehole Yield Analysis}

The yields of these boreholes were measured using a container of 5 liters and a stopwatch. The time to fill the container was recorded and the yield, $\gamma\left(\mathrm{m}^{3} /\right.$ day) was calculated as follows:

$$
\gamma=\frac{\text { Container capacity }}{\text { Time taken to fill container }}
$$

The yield of the boreholes in the villages visited were analyzed and compared. The types of lithologies considered are the granitic terrain and the schist belt [8-10].

\section{The granitic terrain}

i. Massingbi Borehole Yield

Capacity of container $=5$ liters

Time to fill container $=19 \mathrm{~s}$

$\gamma=5 / 19=0.263$ liters $/ \mathrm{s}=15.78$ liters $/ \mathrm{min}=15.78 \times 60 \times 24$ liters $/$ day $=22.72 \mathrm{~m}^{3} /$ day

i. Petifu Line Borehole Yield

Capacity of container $=5$ liters

Time taken to fill container $=21 \mathrm{~s}$

$\gamma=5 / 21=0.238$ liters $/ \mathrm{s}=14.28$ liters $/ \mathrm{min}=14.28 \times 60 \times 24$ liters $/$ day $=20.56 \mathrm{~m}^{3} /$ day

\section{The schist belt}

I. Makoni Line Borehole Yield

Capacity of container $=5$ litres

Time taken to fill container $=24 \mathrm{~s}$

Yield $=5 / 24=0.208$ litres $/ \mathrm{s}=12.48$ litres $/ \mathrm{min}=12.48 \times 60 \times 24$ litres $/$ day $=17.97 \mathrm{~m}^{3} /$ day

\section{Conclusion}

The objective of the research was to map the various rock types and assess the geology and hydrogeology of the area, the potential of the groundwater for water supply in Kunike Sanda and Barina Chiefdoms, Tonkolili District, Northern Provinces, Sierra Leone [11].

Field observations during the mapping helped to unravel the geology of the area. Adequate information about the stratigraphic sequence of the project area during the exercise was difficult to unravel because of poor exposure. However, stream channels helped in unraveling of the geology of the area.

From observations and findings, we concluded that surface water is not reliable because of the excessive pollution tendencies due to dumping of garbage in the water and defecation by inhabitants nearby. Even though the surface water scheme can meet growing demand of the community, there are no funds available to pump the water to the community and to treat the water before use; because of this, many residents depend greatly on ground water for water supply. The boreholes drilled cannot meet the growing demand of the present community. From the analysis above we may conclude that the yield is greater in the granitic terrain than in the schist belt. And this is because of the presence of clays in the schist belt hence the significance of assessing the geology before drilling a borehole of digging a well [12]. 
Citation: Jalloh Y, Sasaki K, Thomas MO (2016) The Influence of Local Geology on the Groundwater Potential of Kunike Sanda and Barina Chiefdoms Tonkolili District Northern Sierra Leone. Hydrol Current Res 7: 262. doi: 10.4172/2157-7587.1000262

\section{Recommendations}

After several findings, the following recommendations should be noted:

1. Instead of drilling a lot of boreholes only to be abandoned after a short period of time, it is noteworthy that the implementing agencies should be monitored so that all the problems if not all, some reported by the community be easily solved.

2. Regular maintenance of the boreholes should be done on a frequent basis at least once every three (3) months, whereby SALWACO Personnels visit the community to conduct water quality tests and advise them [13].

3. New boreholes should be drilled in every village to alleviate the problem of water shortage and these boreholes should be handled with care.

\section{References}

1. Marmo V (1962) Bulletin No 2. The Geology and Mineral Resources of The Kangari Hills Schist Belt, Geological Survey of Sierra Leone.

2. Jalloh $A B$ (2009) The geology and hydrogeology of Kunike Sanda and Barina Chiefdoms, Tonkolili District, Northern Sierra Leone. BSc Thesis, Fourah Bay College, University of Sierra Leone.

3. Pritchard M, Mkandawire T, O'neill JG (2008) Assessment of groundwater quality in shallow wells within the southern districts of Malawi. Physics and Chemistry of the Earth 33: 812-822.
4. Ministry of Energy and Water Resources (2010) The National Water and Sanitation Policy, Federal Government of Sierra Leone.

5. Day J (2012) Mapping progress and the challenges ahead in Sierra Leone Waterlines 31: 306-308.

6. Harvey P (2007) Sustainable Rural Water Supplies. UNICEF [Online] http:// www.watsan.org/docs/2007-data-on-number-of-broken-down-handpumps-inAfrica.pdf (Accessed on 21st July 2012).

7. Cooper HH, Jacob CE (1946) A generalized graphical method for evaluating formation constants and summarizing well field history. Trans American Geophys Union 27: 526-534.

8. Dixey F (1925) The Geology of Sierra Leone. Geological Society London.

9. Wright JB, Hastings DA, Jones WB, Williams HR (1985) Geology and Minera Resources of West Africa. Allen and Unwin, London, UK.

10. William HR (1978) The Archaean geology of Sierra Leone. Elsevier Scientific Publishing Company, Amsterdam, The Netherlands.

11. Ministry of Mines and Mineral Resources (2011) An Overview of the Mineral Sector in Sierra Leone, Government of Sierra Leone, Available from: http:/l www.sIminerals.org

12. United Nations Development Programme (2013) Sierra Leone HDI values and rank changes in the 2011 Human Development Report UNDP 2011. Accessed on 8th January 2013

13. Wilson NW, Marmo V (1958) The Geology, Geomorphology and Minera Resources of the Sula Mountains. Geological Survey Sierra Leone Bulletin No 1. 